\title{
Domestic Sources of International Environmental Policy: Industry, Environmentalists, and U.S. Power, by Elizabeth DeSombre, Cambridge, MA: The MIT Press (2000), xvi and 300 pp.
}

\author{
Reviewed by Dimitris Stevis, Department of Political Science, Colorado State University, \\ Fort Collins, CO.
}

Since the late 1980s international relations scholars have increasingly sought to apply theoretical insights to the empirical study of various aspects of international environmental politics. Elizabeth DeSombre's volume is a welcome and valuable addition to this growing literature contributing, primarily, to understanding the domestic sources of international environmental policy, as the title of her book suggests. After presenting her major arguments and findings I identify some future or relevant avenues of research that this project suggests, either implicitly or explicitly. Every researcher chooses her areas of interests and research and, in any event, there is only so much that any one of us can do. In that sense, these latter comments do not detract from DeSombre's solid theoretical and empirical work. But because the theoretical and substantive issues that she raises are contested issues I find it appropriate to situate her volume within a broader context.

In her words, "one important way that regulations in general appear on the international scene is through the internationalization of regulations that one or more states have undertaken domestically" (p. 2). She proceeds to examine this proposition through the practice of the U.S. in the areas of endangered species, air pollution and ocean fisheries. She recognizes, however, that trying to internationalize a domestic policy is not the same thing as having it accepted by other countries. For this reason she divides the overall process into two "stages". Stage I deals with the politics of attempting to internationalize a domestic policy; Stage II deals with the question of the success of such an attempt. The first part of the book (Chapters 3 - 5) "argues that we should expect to find attempts at internationalization when domestic economic and environmental interests combine to benefit from adoption by other states of the environmental regulations in question" (p. 14). The second section (Chapters 6 and 7) "argues that target states will adopt the regulations pushed by internationalizing states that make a credible threat to impose sanctions in an area in which it [sic] has dominant market powers" (p. 14). On the basis of her research, DeSombre identifies some key implications or, perhaps, possible lines of additional research. One key implication is that of alliances between industry and environmentalists in promoting the internationalization of domestic regulations. A second implication is that crosscutting alliances may also be present in other issue areas. A third implication relates to the effectiveness of sanctions. According to the author, sanctions may actually work well under specific conditions. A final implication is "that domestic politics and international relations are not distinct entities"(p. 17). Moving between the author's "Introduction and Overview" and the relevant chapters of the book I will deal with the two stages in their temporal order.

Stage I involves "the conditions under which the United States will attempt to internationalize domestic environmental regulations" (p. 9). Professor DeSombre identifies two general explanations. The environmental explanation posits that "environmental externalities will drive attempts to encourage other states to adopt environmental regulations similar to those of the United States" (p. 9). The economic explanation "looks to the economic harm suffered by the regulated domestic industries and the potential for economic gain offered by internationalization" (p. 9). Her answer is that the U.S. “... typically pushes to internationalize those domestic environmental policies that would be advantageous on the international level for both economic and environmental reasons" (p. 10). In fact, she finds that "in no case ... is one set of actors able to push forward an attempt at internationalizing without engaging the interests of the other group" (p. 10).

Chapter 2 provides the research questions and research design for Stage I. After reviewing the alternative environmental and economic explanations. DeSombre states her argument more clearly and evocatively. She argues that attempts at internationalization are more likely to take place when 'Baptists' (environmentalists) and 'bootleggers' (industry) ally with each other. In particular "we should expect a push for internationalisation most frequently when domestic regulation causes trade externalities for the regulated industry within the United States" 
Reviews

(p. 45). Even though 'competitiveness' arguments carry the day, however, "it is important that there be an environmental reason to internationalize regulation" (p. 46). The three sets of cases (endangered species, air pollution and ocean fisheries) she examines in Chapters 3 - 5 uphold the basic parameters of this argument. The author, however, is careful to point out variations and modifying conditions.

Stage II deals with the question of whether the U.S. is successful in internationalizing domestic policies, and also offers explanations for such success. The "legitimacy" explanation posits that "a state will adopt regulations because it thinks doing so is the "right" thing to do regardless of self-interest or fear of consequences." The "selfinterest" explanation posits "... that a state will adopt a regulation pushed by another state," if it is in its interest to do so. The "threat" explanation posits that a state will adopt a policy if it "fears that it will be harmed by the other state if it does not do so" (p. 12). DeSombre's argument “... relies most heavily on the variant of the realist hypothesis, but also relies on the credibility gained from the involvement of the coalition of environmental and economic interests observed at Stage I" (p. 12). In particular, "the most important aspect in predicting success is the market power that the internationalizing state has over the states it is trying to persuade, relative to the costliness to the target state of adopting the regulation" (p. 13).

In Chapter 6, the author discusses the various explanations in more depth. As noted above and restated at the end of this chapter, the cases demonstrate that the U.S. has its greatest success in cases when "the sending state has a high degree of relative market power in the threatened resource, with that resource inherently related to the environmental issue over which the regulation is sought" (p. 171). Chapter 7 presents a detailed examination of evidence relevant to this proposition. In this chapter DeSombre discusses specific cases within each one of the three issue areas and the responses of the various target states. The author recognizes that there is variation across issues and countries (p. 225), with the ozone case being the most successful and efforts at persuading others to regulate tuna fishing within their EEZs being a failure (pp. 225-226).

On the basis of her detailed examination of these cases the author proceeds to evaluate the merits of each explanation. She finds that the "legitimacy" explanation does not seem persuasive because there seems to be no relationship between high legitimacy policies (for instance those adopted through multilateral means) and positive response to U.S. efforts (p. 229). The second explanation that the author examines is that of "environmental selfinterest," i.e., that a target state may choose to comply because compliance will confer come environmental benefits. As the author suggests, her study seems to pick-up those instances where the internationalization of environmental regulation is contentious (p. 231). As a result, this explanation may carry more weight than is apparent. In the case of the contentious cases, however, environmental self-interest does not seem to play a dominant role (p. 234). The third explanation, "threats," does seem to play a more important role. According to the author, the impact of threats varies depending on "the power of those making the threat, the credibility of that threat, and the cost to the target state of suffering the consequences of refusing to change behavior "(p. 237). She concludes that the most successful internationalization attempts are found in cases where the sending state stands to gain the most from imposing sanctions (p. 238) such as prohibiting a major competitor's access to its markets. This leads to the last explanation, market power. The author's view is that the combination of credible threats with market power (in the specific issue area involved) is the best predictor of internationalization success. Moreover, the credibility of the threat increases if there is a strong Baptist-bootlegger alliance in Stage II, as well. Such an alliance will push for sanctions and will ensure that the state actually pursues them.

Central to the author's project is the necessity of an industry-environmentalist alliance (bootleggers and Baptists) before an internationalization attempt (operationalized as Congressional legislation) can get off the ground and, also, in making threats credible. In her discussion of "lessons for environmentalists," and elsewhere, the author points out that "Baptists create bootleggers and should be advised to consider what types of concerned actors will contribute most in the long run to international environmental regulation" (p. 251). The author would agree that bootleggers also create Baptists. But neither Baptists nor bootleggers are unitary categories, whether at the beginning of such a mutually engendering process or during the course of it. As a result, the potential for alliances involving particular Baptists and bootleggers is ever present and clearly evident in the U.S. foreign policy record (Audley 1997). The kinds of alliances that are formed and their reasons, justifications, and longevity are central to the study of the "greening of industry" and the "marketization of environmentalists" so prominent in our days.

This convergence is particularly important because, as DeSombre observes, industry does have a preponderant role. Throughout the book, it is apparent that industry does not simply bring its concerns about competitiveness to the table but, also, its "structural power". On the other hand, environmentalists bring not only environmental sensitivity, but also legitimacy. The final fusion is an uneven synthesis. From one point of view, this synthesis may be seen as the introduction of environmental sensitivity into the behavior of industry (Vogel 1995, Hawken et al. 2000). From another point of view it can be seen as the subjugation of environmentalists to the hegemony of capital ("weak ecological modernization") (Christoff 1996, Mol and Spaargaren 2000). Whoever has

116 Vol. 82001

Journal of Political Ecology 
Reviews

the upper hand shapes, in my view, not only particular policies but, also, second order rules, i.e., the rules that delineate which policies are legitimate and feasible. To illuminate this point, the examination of the various disputes brought to the WTO is important in its own terms and adds to our understanding of world politics. Yet, there is a good case to be made that the WTO represents a certain order of things that makes some issues important and relevant while it delegitimates others.

The above is important because, as DeSombre is right in pointing out, such alliances may occur in other issue areas. A prime example of that would be U.S. labor policies during the 1940s and, again, the use of domestic trade policies to enforce international labor standards since the late $1970 \mathrm{~s}$. As with the environmentalist-industry case, the labor-industry case worked on various levels and, also, differently across time. On one level, during the 1940s elites within industry and the unions did find common ground and, thus, marginalized recalcitrant business leaders and radical unions; on another level, this accommodation cast unions in a subordinate role with long term implications. Labor's junior role is also evident in the various attempts at using trade laws to enforce labor standards abroad.

A related issue I would like to raise here is that the role of the state, other than as a recipient and processor of societal pressures, is not examined even though it is ever present. The author can well argue that she has shown that alliances between environmentalists and industry are sufficient explanations. Such an approach, legitimate as it may be, carries with it important substantive and theoretical implications and ought to be discussed. Alternatively, we can be left with the impression that the state simply responds to the instrumental interests of particular social forces regardless of the implications for broader state or societal priorities. The author's argument would have been strengthened if this issue was addressed, both theoretically and through one of these or some other, more appropriate, case. This is particularly important because during critical points in U.S. history, such as the formation of the post-WWII economic order and its reorganization in the 1980s and with respect to critical issue areas, such as climate change and nuclear power, state agencies take a leading role. It is quite possible, for instance, that states may not want sanctions to succeed if the broader edifice is likely to be compromised.

A third issue that DeSombre raises is that her study does contribute to the understanding of the domesticinternational divide. There is no denying that her study does contribute well to the study of that divide. Here I would like to point out, however, that the arguments regarding the fuzziness of this divide are much earlier than the late 1980s, as exemplified by works from the whole spectrum of international politics, including historical materialists, dependency theorists and liberal institutionalists. The issue, therefore, is how that divide is conceptualized and treated. The increasing vertical and horizontal integration of firms and the internationalization of the state may, in fact, militate in favor of a more historical and sociological view of the constitution of social agents and of their preferences (e.g., Cox 1987, Ruggie 1995) than the "game theoretic" discourse can accommodate.

A final issue is whether one can generalize from the United States experience to the rest of the world. I agree with DeSombre that there is evidence that similar cases do obtain in other countries. Yet, it would seem to me that the experiences of dominant countries or dominant state-society alliances (whether domestic or transnational) are different from those of subordinate ones. Is it the case, perhaps, that what is interesting with the former is the process of attempting to internationalize domestic policies while with the latter, the process of trying to adjust to such efforts? The author's evidence in Chapter 7 raises some intriguing ideas in this direction.

In my view, DeSombre's volume would have been well served by the allocation of a chapter to the discussion of broader structural issues - whether with respect to the Baptist-bootlegger alliance, the role of the state, or the different experiences of dominant and subordinate social forces. Yet, this may well be outside of the author's interests and she cannot be faulted for that, nor is the value of this fine book diminished as a result. My goal in commenting on some of the contextual issues above has been to situate the volume while asserting its positive contribution to the growing literature on international environmental politics.

\section{References Cited:}

Audley, John.

1997. Green Politics and Global Trade: NAFTA and the Future of Environmental Politics. Washington, DC: Georgetown University Press.

Christoff, Peter.

1996. Ecological Modernisation, Ecological Modernities. Environmental Politics 5(3): 476-500.

Cox, Robert.

1987. Production, Power and World Order: Social Forces in the Making of History. New York: Columbia University Press.

Hawken, Paul, Amory Lovins and L. Hunter Lovins. 
Reviews

1999. Natural Capitalism: Creating the Next Industrial Revolution. Boston: Little, Brown and Company. Mol, Arthur P.J. and Gert Spaargaren.

2000. Ecological Modernisation Theory in Debate: A Review. Environmental Politics 9(1): 17-49.

Ruggie, John Gerard.

1995. At Home Abroad, Abroad At Home: International Liberalisation and Domestic Stability in the New

World Economy. Millennium 24(3): 507-526

Vogel, David.

1995. Trading Up: Consumer and Environmental Regulation in a Global Economy. Cambridge, MA: Harvard University Press.

\section{Brave New Seeds: The Threat of GM Crops to Farmers, by Robert Ali Brac de la Perriere, and Franck Seuret. London: Zed Books (2000), 160 pp.}

\section{Reviewed by Glenn Davis Stone, Department of Anthropology, Washington University, St. Louis MO 63130.}

This little book, with a bold title and backed by an aggressive marketing campaign by Zed Books, is the latest entry into the turbulent debate on genetically modified (GM) crops. The preface introduces it as one of a series of "short, accessible think pieces" on global issues. That's true in the sense that the book tells what some people think about GM crops. It's not true in the sense of "thinking through" an issue, or even offering new thoughts.

The authors are an "international consultant" and a journalist, and the people whose thoughts they report on were 39 conferees who met in India in December of 1998. Most are from India or western Europe, with a few Africans, North Americans, and Latin Americans. It is unclear how the group was selected, but it was not on the basis of contributions to the scientific or social science literature on GM crops. Their meeting is claimed to have been a "multicultural debate" on GM agriculture (p. 3) but there is no sign of debate in the book; it's pure green polemic, beginning and ending with the conviction that GM agriculture "threatens to carry away all that remains of the fabulous vegetal heritage gathered down the ages" by farmers in India and elsewhere in the developing world (pp. 1-2).

The anti-GM arguments are presented in 7 chapters such as "Terminator, Out!" and "About Ethics: Tampering With the Foundations of Life." The claims will be familiar to most readers: GM crops are likely dangerous to human health and the environment, they threaten farmer independence (in fact, are part of the "programmed elimination of small farmers"), they will endanger southern countries' control over their agricultural germplasm, and they aren't needed anyway because hunger results from inequalities rather than shortages.

The book exemplifies the regrettably polarized character of the debate on GM crops. This has turned into a spin war that pushes both sides to devious positions (Stone 2000): corporate media touts a disingenuous malthusianism and inflated claims on the humanitarian benefits of their products, while green critics obstinately deny that GM crops have any promise whatsoever. A case in point from this book is the issue of apomixis -- the property of asexual reproduction, occurring naturally in some plants and apparently transferrable to new plants. While GM today is widely associated with "Terminator" technology which would remove farmer control over seed reproduction, the development of apomictic plants through genetic modification would allow increased farmer control. All hybrid seeds are "terminator" seeds in that heterosis (hybrid vigor) is lost in the second generation. But apomixis could lock the benefits of heterosis into a replantable pure line. Progress has been slow using conventional breeding techniques, and genetic modification promises to greatly expedite research. It is not yet known how this apomixis technology will affect farming in the south (Bicknell and Bicknell 1999), but clearly the potential is enormous. Remaining true to the polarized debate, Brave New Seeds claims apomixis to be no more than a means for seed companies to reduce production costs, while reducing plants' capacity to adapt to changes in the environment (p. 35). Another example: researchers in non-commercial labs have developed cassava resistant to the mosaic virus that ruins part of the African harvest each year; this is a vegetatively reproduced crop that could remain outside of corporate control. How these technologies are deployed, and how we are to weigh their risks and benefits, are crucial issues for agriculture in the south, certainly deserving of a more open-minded airing than they receive

$118 \quad$ Vol. 82001

Journal of Political Ecology 